\title{
FANTONI'S TRACHEOSTOMY USING CATHETER HIGH FREQUENCY JET VENTILATION
}

\author{
P. Török, A. Hermely, P. Candík, M. Jakubová, \\ I. Sopko, D. Rybár, S. Saladiak, V. Donič̌, E. Benčíková
}

Clinic of Anaesthesia and Intensive medicine, Eastern Slovakia Cardiovascular Institute of Medical Faculty, University of P. J. Šafarik, Košice, Slovakia

${ }^{1}$ Dept. of Medical Physiology, Medical Faculty, University of P. J. Šafarik, Košice, Slovakia

\section{Трахеостомия по Фантони с использованием высокочастотной струйной вентиляции легких}

\author{
P. Török, A. Hermely, P. Čandík, M. Jakubová, \\ I. Sopko, D. Rybár, S. Saladiak, V. Donič ${ }^{1}$, E. Benčíková
}

Клиника анестезиологии и реаниматологии, Восточно-Словацкий Институт сердечно-сосудистых заболеваний
медицинского факультета Университета им. Р. J. Šafarik, Кошице, Словакия
${ }^{1}$ Кафедра медицинской физиологии медицинского факультета Университета им. Р. J. Šafarik, Кошице, Словакия

\begin{abstract}
Background: It has been shown previously that conventional ventilation delivered through a long cuffed endotracheal tube is associated with a high flow-resistance and frequent perioperative complications. Aim: We attempted to supersede the conventional ventilation by high-frequency jet ventilation through a catheter (HFJV-C) and assess safety of the procedure. Material and methods: Using a translaryngeal tracheostomy kit, we performed a translaryngeal (Fantoni) tracheostomy (TLT). Subsequently, we introduced a special 2-way prototype ventilatory catheter into the trachea via the TLT under bronchoscopic control. Satisfactory HFJV-C ventilation through the catheter was achieved in 218 patients. Results: There were no significant adverse effects on vital signs observed in the cohort during the study. The $\mathrm{pH}, \mathrm{SpO}_{2}, \mathrm{PaO}_{2}$, and $\mathrm{PaCO}_{2}$ did not change significantly following the HFJV-C. The intrinsic PEEPi measured in trachea did not exceed $4-5 \mathrm{~cm} \mathrm{H}_{2} \mathrm{O}$ during its application, which was significantly less than during the classical ventilation via the endotracheal tube fluctuating between 12 and $17 \mathrm{~cm} \mathrm{H}_{2} \mathrm{O}$. No serious medical complications occurred. Conclusion: The HFJV during Fantoni's tracheostomy using the catheter HFJV-C proved to be a safe and effective method of lung ventilation at the intensive care unit. Key words: Translaryngeal tracheostomy, HFJV via catheter.
\end{abstract}

Введение. В течение длительного времени известно, что традиционная вентиляция легких через интубационную трубку с манжеткой сопровождается высоким сопротивлением потоку и частыми периоперационными осложнениями. Цель. Предприняли попытку заменить традиционную вентиляцию легких на высокочастотную струйную вентиляцию через катетер (ВЧ ИВЛ) для оценки безопасности данной манипуляции. Материал и методы. Трансоларингеальная трахеостомия (по Фантони) была выполнена с использованием стандартного набора инструментов. Затем специальный двухходовой катетер для ВЧ ИВЛ был заведен в трахею через трахеостомическое отверстие под контролем бронхоскопа. Мы добились успешной ВЧ ИВЛ у 218 больных. Результаты. Значимых побочных эффектов в группах больных зарегистрировано не было. $\mathrm{pH}, \mathrm{SpO}_{2}, \mathrm{PaO}_{2}$ и $\mathrm{PaCO}_{2}$ достоверно не изменялись во время ВЧ ИВЛ. АутоПДКВ, измеренный в трахее, не превышал 4-5 см водн. ст. во время процедуры, что было достоверно ниже, чем при проведении стандартной вентиляции легких через интубационную трубку (12-17 см водн. ст.) Других серьезных осложнений не было зарегистрировано. Выводы. ВЧ ИВЛ через трансларингеальную трахеостому (по Фантони) с использованием катетеры безопасна и эффективна для вентиляции в отделении реаниматологии. Ключевъе слова: трансларингеальная трахеостомия, ВЧ ИВЛ через катетер.

Translaryngeal tracheostomy (TLT) was first presented in 1993 and after a few adjustments first published in $1995(1,2)$. It is based on the translaryngeal (retrograde) principle of tracheal dilation by the tip built into the tracheostomic introductory tube and a cannula from the trachea transcutaneously outwards (2-4). The advantage of TLT is the technique of minimal invasiveness and minimal damage to the trachea, which can be a problem at surgical

Адрес для корреспонденции (Correspondence to):

Pavol Török

E-mail: torokp@t-zones.sk and punctural dilatation tracheostomy (5). Contrary to the punctural dilatation tracheostomy it is not necessary to use forceps or other expansion devices, causing further damage to the surrounding tissue. Using an integrated dilator associated with the cannula ensures continuous development of tissue adhesion at the stoma (3). It causes no instrumental dilatation of the tracheal wall and thus minimizes bleeding and inflammation (5.9). This procedure represents a minimal damage to blood vessels, because vessels are pushed away by the tip of expansion cannula.

The original TLT set for artifitial lung ventilation (ALV) uses a long and relatively narrow cannula (ID $/ \mathrm{ED}=$ 5/7.5-8 mm), Such ET cannula with a balloon (Fig. 1) 
induced just above the carina, has several major drawbacks. During rotation of the tracheostomy cannula in the relatively narow trachea, the turning of the tracheostomy cannula can be impeded. Substantially greater problem is the resistance (Rt) of the ET cannula, which under normal circumstances is $40-60 \mathrm{~cm} \mathrm{H}_{2} \mathrm{O} . \mathrm{l}^{-1} \cdot \mathrm{s}^{-1}\left(=4-6.5 \mathrm{kPa} \cdot \mathrm{l}^{-1} \cdot \mathrm{s}^{-1}\right)$. Fig. 1. At relatively normal lung mechanics, generated during the ALV with conventional frequencies $\left(14-18 \mathrm{c} . \mathrm{min}^{-1}\right.$ and $\mathrm{Vt}=400$ to $700 \mathrm{ml}$ ), the positive end expiratory pressure - PEEPi (auto PEEP) reaches $12-17 \mathrm{~cm} \mathrm{H}_{2} \mathrm{O}(=1.7 \mathrm{kPa})$. This is far from negligible values and can have significant negative impact on the ventilation and circulation of the patient. From the above reasons after risk analysis with using the original ET cannula, we replaced it and started to apply ALV through a tracheostomy using a high frequency jet ventilation catheter (HFJV-C). The principle design of jet generator in HFJV-C is based on the general structure and physical characteristics of the jet generator (Fig. 2).

Jet generator in this form is the trachea (cylindrical cavity - receiving channel) and a catheter with nozzle, which is located in the trachea. The catheter form of HFJV represents jet ventilation at conventional frequencies, providing satisfactory ventilation, which can be clearly preferred for tracheobronchial reconstructive surgery, laryngeal surgery, and operations in large open airways for the following reasons:

- It insures adequate exchange of blood gases during surgery of the airways. The small dynamic PEEPi (up to $5 \mathrm{~cm} \mathrm{H}_{2} \mathrm{O}$ ) increases FRC and stabilizes the geometry of the alveolar compartment (6).

- The ventilation is secured with a thin catheter (not requiring intubation cannula), saving space for the surgeon operating in the field, which allows better handling of instruments used at the operation.

- Movement of the aiways and the mediastinum is reduced.

- The accompanying (Klain's effect) «prevention of aspiration» prevents inflow of blood, saliva and mucus in the airways. This prevents any entrance of blood or secretions into the distal airways $(6,7,8)$. The above advantageous properties of HFJV-C led us to apply this method in TLT by Fantoni.

\section{Material and methods}

For TLT we used a flexible bronchoscope and a «Translaryngeal tracheostomy» kit (Malincrodt Medical GmbH, Hennef, Germany). For ensuring effective ventilation during TLT we provided high-frequency jet ventilation with a special catheter (HFJV-C). Its aplication provides specific benefits that are derived from the structure and physical characteristics of the jet generator. The insufflation catheter together with a catheter measuring pressure in the trachea and a metal stabilizer shape in one «package», have outer diameter of about $4.7 \mathrm{~mm}$, which is about half of the original ET cannula. Catheter from an original set has a length of $27-28 \mathrm{~cm}$. The internal diameter of the insufflation catheter (nozzle) for application of insufflated gas (Pin) is $2.5 \mathrm{~mm}$. A parallel catheter of $1.5 \mathrm{~mm}$ thickness is designed for a system monitoring pressure in the trachea. The catheters were chemically sterilized and their scheme is on Figure 3. Photo of the catheter ready for use is on

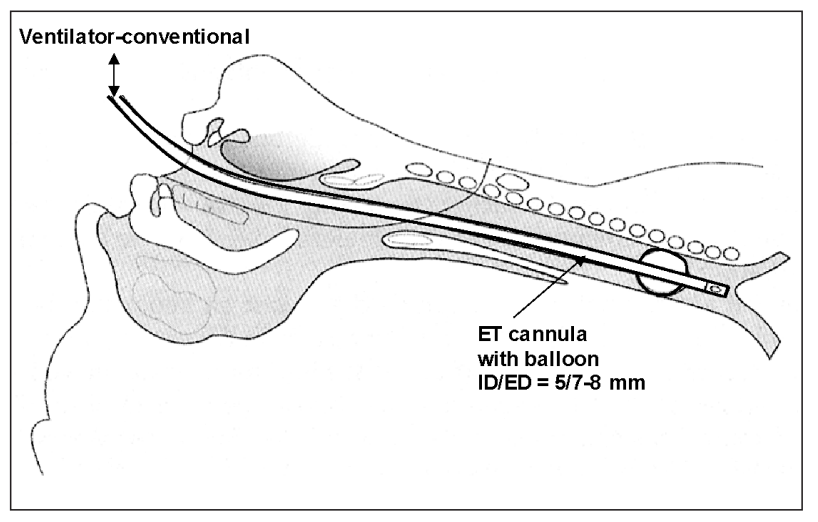

Fig. 1. Insertion of small diameter ET tube used by Fantoni tracheotomy.

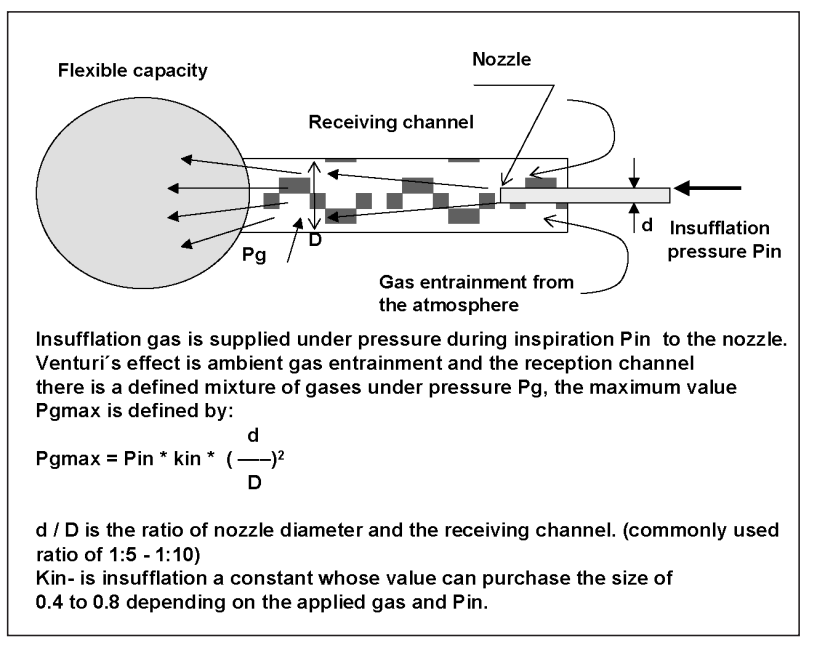

Fig. 2. Physical principes of pneumatic generator using catheter for HFJV.

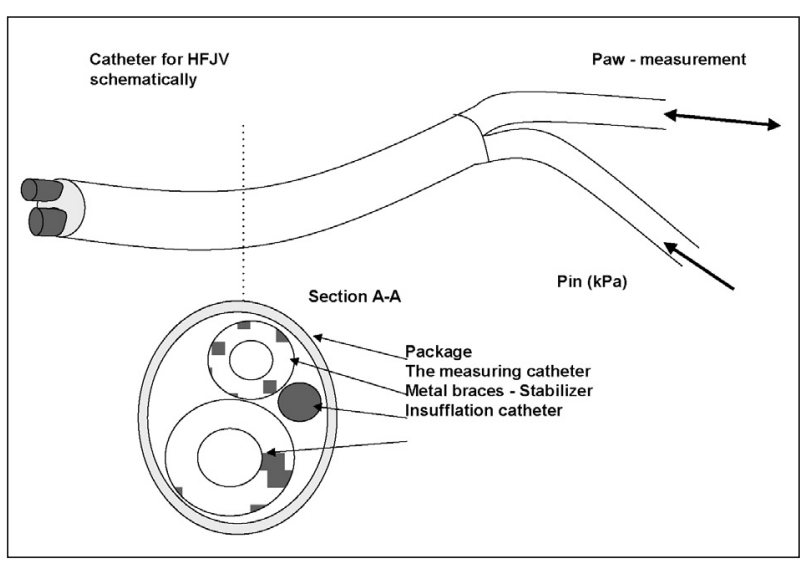

Fig. 3. Scheme of catheter for HFJV.

Figure 4. The introduction of the catheter into the trachea is shown in Figure 5.

Fantoni's tracheostomy method was applied by using the HFJV-C in 218 patients, where several key parameters of the possible negative effects on gas exchange, as well as our own technique of TLT, were tested. Demographic data of our patients and «Euroscore» (standard) of well compensated cardiological patients' are in Table 1. The HFJV-C we performed in general iv anaesthesia with myorelaxation. A bolus dose of Propofol $1.5 \pm 0.8 \mathrm{mg} \cdot \mathrm{kg}^{-1}$ was aplied, with following continuous propofol at a dose of $2 \pm 1 \mathrm{mg} \cdot \mathrm{kg}^{-1} \cdot \mathrm{h}^{-1}$. Atracurium at a dose of 
Demographical data

\begin{tabular}{lcccc}
\hline Number of pat. & Weight (kg) & Age (year) & Admission Euroscore (Standard) & Hosp days \\
\hline 218 & $77,1 \pm 14,1$ & $70,1 \pm 9$ & $9,8 \pm 1,75$ & $7 \pm 1,7$ \\
\hline
\end{tabular}

Table 2

$\mathrm{PaO}_{2}$ and $\mathrm{PaCO}_{2}$ before tracheostomy and after tracheostomy usinf $\mathrm{HFJV}$ catheter ventilation

\begin{tabular}{lccc}
\hline & Pat. No & n=218 & Student $\boldsymbol{t}$-test \\
\hline Before TS & $\mathrm{PaO}_{2}(\mathrm{kPa})$ & $10,7 \pm 2,8$ & \\
After TS & $\mathrm{PaO}_{2}(\mathrm{kPa})$ & $11,1 \pm 3,2$ & $\mathrm{NS}$ \\
Before TS & $\mathrm{PaCO}_{2}(\mathrm{kPa})$ & $4,5 \pm 0,44$ & \\
After TS & $\mathrm{PaCO}_{2}(\mathrm{kPa})$ & $4,2 \pm 0,39$ & $\mathrm{NS}$ \\
\hline
\end{tabular}

0.5mg. $\mathrm{kg}^{-1}$ and at a dose of $0.5 \mathrm{ug} \cdot \mathrm{kg}^{-1}$ were added. We continuously monitored blood pressure (BP), puls (P), airway pressure (Paw), saturation of $\mathrm{O}_{2}\left(\mathrm{SpO}_{2}\right)$, laboratory measurements of acid base ballance (ABR) before and just after the HFJV-C. We studied and compared the problems of turning Fantoni`s cannula, as well as the emergence of PEEPi, applied Paw a leakage through the larynx, or bleeding after the introduction of the cannula.

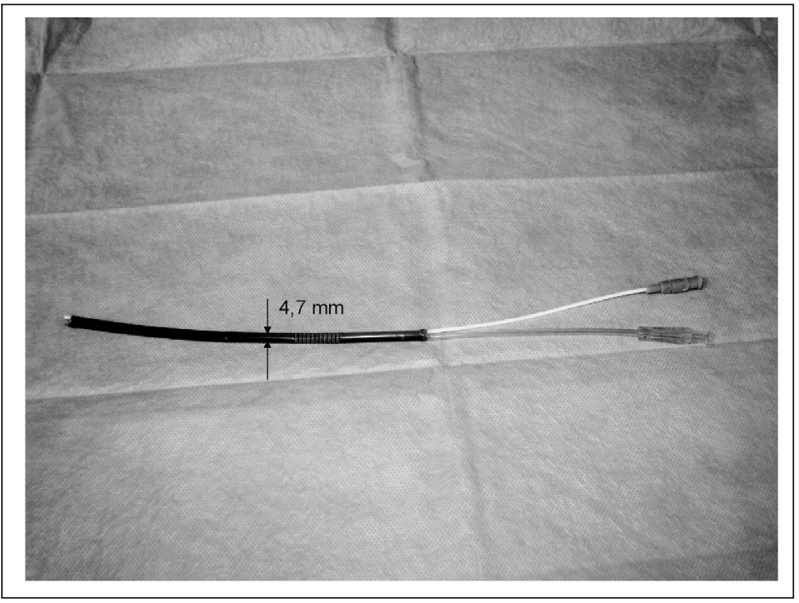

Fig. 4. HFJV catheter
A clear contraindication of HFJV is in status asthmaticus, or states with very high airway resistance and in acute decompensated obstructive bronchopulmonary disease, non- responding to treatment. The border for ventilation failure with $\mathrm{FiO}_{2}$ from 0.65 to 0.8 is at a minute ventilation of $190-200 \mathrm{ml}^{-\mathrm{kg}^{-1}}$. $\min ^{-1}$. Therefore, HFJV-C was not used in such cases for the possibility of a relative hypoventilation, or hypoxemia, because the pressure generator consisting of a nozzle - catheter, receiving channel and trachea provide a gas mixture containing only about $50-60 \% \mathrm{O}_{2}$. We used a ventilator PARAVENT PAT-e (Chirana-medical, SR), which is structurally designed as an electronically controlled high-frequency jet ventilator with optimal frequency of $120 \mathrm{c} . \mathrm{min}^{-1}$ (or 20 and $40 \mathrm{c} \cdot \mathrm{min}^{-1}$, respectively). The optional time of inspiration (Ti) is $33 \%, 50 \%$, or $66 \%$ and the optional power of insufflation (Pin) from 0 to 300 $\mathrm{kPa}$. There are alarms of apnoe, hypoventilation and pressure limit for peak inspiratory pressure $(\mathrm{PiP}=\mathrm{Pt}-$ tracheal pressure $)$ in the airways. At the limit $\mathrm{PiP}\left(\mathrm{Pt}=40-45 \mathrm{~cm} \mathrm{H}_{2} \mathrm{O}\right)$ the device will interrupt the ventilation. During application of HFJV-C, the peak tracheal pressure was only $15-35 \mathrm{~cm} \mathrm{H}_{2} \mathrm{O}$ and PEEP $=3-4 \mathrm{~cm} \mathrm{H}_{2} \mathrm{O}$.

Given the fact that HFJV-C application is over 17 years in routine practical use for ventilation, the local ethics committee approval was not deemed necessary. Informed patient consent to such application, however, is always required preoperatively.

Methodology. After extubation of orotracheal cannula the HFJV-C is introduced into the trachea during direct laryngoscopy to a depth of $6-8 \mathrm{~cm}$ below the vocal cords, $2-3 \mathrm{~cm}$ above the carina, respectively, as indicated on Figure 4. After turning on the ventilator with selected ventilatory parameters as shown in Table 4, it is necessery to check auscultatory signs of ventilation and to monitor circulation and $\mathrm{SpO}_{2}$. A flexible fiberoptic bronchoscope (FFB) is introduced up to the point of planned tracheostomy. The normal level is the second inter-anular space, however, the access may be also at higher or lower level. In patients after sternotomy a higher access is choosen to allow a larger distance of the puncture hole from the wound. The selection depends on anatomical circumstances, which allows identification of the optimal puncture site. If necessary, the selected area is pushed up by the top of FFB, which depletes the tissue and improves trans-lumination. For thicker necks, where the candling is difficult, we are using a 
Duration of orotracheal intubation before tracheostomy and duration of the tracheostomy procedure in first 20 patients

\begin{tabular}{lcc}
\hline $\begin{array}{l}\text { Duration of OTI (orotracheal intubation) } \\
\text { (days) }\end{array}$ & $\begin{array}{c}\text { TS (tracheostomic) } \\
\text { kannula }(\mathbf{m m})\end{array}$ & $\begin{array}{c}\text { Duration of perforamnce (min - rounded) } \\
\text { First 20 performances }\end{array}$ \\
\hline $7 \pm 2,7$ & $7,0-8,5$ & $27 \pm 12$ \\
\hline
\end{tabular}

Duration of orotracheal intubation before tracheostomy

Table 4 and duration of the tracheostomy procedure in last 20 patients

\begin{tabular}{lcc}
\hline $\begin{array}{l}\text { Duration of OTI (orotracheal intubation) } \\
\text { (days) }\end{array}$ & $\begin{array}{c}\text { TS (tracheostomic) } \\
\text { kannula }(\mathbf{m m})\end{array}$ & $\begin{array}{c}\text { Duration of perforamnce (min - rounded) } \\
\text { First 20 performances }\end{array}$ \\
\hline $6 \pm 2,3$ & $7,0-8,5$ & $15 \pm 4$ \\
\hline
\end{tabular}

Table 5

Technical complications during tracheostomy procedure

\begin{tabular}{|c|c|c|}
\hline Technical complications & Number & $\%$ \\
\hline Damage of balloon TT cannula - reinserction & 2 & 0,92 \\
\hline Bleeding into the trachea after the needle puncture - without bung up into the trachea and without intervention & 5 & 2,29 \\
\hline Overpressure and stop HFJV for more than 15 seconds & 7 & 3,21 \\
\hline Ejection of the cannula to move the driver? & 1 & 0,46 \\
\hline Introduction of guide wire caudal - reinsertion & 2 & 0,92 \\
\hline Wall puncture without perforation of bronchoscope & 6 & 2,75 \\
\hline Together & 23 & 10,55 \\
\hline
\end{tabular}

finger to localize the end of FFB. The TLT procedure itself used by us is described in the author's methodological papers $(1,2)$, as well as in instructions for use of TLT (Malincrodt Medical $\mathrm{GmbH}$, Hennef, Germany). HFJV-C designed for tracheostomy is a defined catheter (nozzle) introduced with a measuring line in the trachea about $2-3 \mathrm{~cm}$ above the carina. Before balloon inflation via a TS cannula, after switching off the ventilator and the HFJV-C is extracted from the trachea. Via TS cannula the balloon is inflated, the cannula is fixed and the patient is connected to a conventional ventilator. For exchange of the cannula, if needed, the 5th postoperative day can be used, which will create a good stable channel in the surrounding tissue, allowing the introduction of a new cannula without the use of instrumentation and FFB. We performed tracheostomy using the HFJV-C in $90 \%$ at a small but potential risk of infectious aerosols in a «septic» box.

\section{Results}

During general monitoring of the basic vital functions no major changes were observed in either case. A slight decrease in systolic BP by about $15 \pm 5 \mathrm{~mm} \mathrm{Hg}$ after anaesthesia is considered a normal phenomenon. Patients before the introduction of HFJV-C were in pressure controlled ventilation (PCV) mode with VT about $6.2 \pm 0.8 \mathrm{ml} . \mathrm{kg}^{-1}$ of body weight, at respiratory frequency of $17 \pm 3.2 \mathrm{~b} \cdot \mathrm{min}^{-1}, \mathrm{PEEP}=7 \pm 2 \mathrm{~cm} \mathrm{H} \mathrm{H}_{2} \mathrm{O}$ and $\mathrm{FiO}_{2}=0.45 \pm 0.05$.

The key variables that interested us were the changes in blood gases during and after application of HFJV-C. When comparing the changes in $\mathrm{pH}$, we found no significant alterations. The gas exchange was also normal and $\mathrm{SpO}_{2}$ ranged from 92 to $99 \%$, without significant deviations. We compared the blood gases before connecting the patient to the HFJV-C and just after the detachment of HFJV-C. $\mathrm{FiO}_{2}$ before the connection to HFJV-C had an average value of $0.45 \pm 0.05$. The $\mathrm{FiO}_{2}$ values result- ing from the function of jet generator varied from 0.5 to 0.6 , depending on the characteristics of the lung mechanical properties and the ratio of diameters of the ventilation catheter and the tracheal lumen. The values of blood gases are in Table 2.

Comparison of the results by paired Student $t$-test indicated no significant differences in blood gas values before and after application of TS with HFJV-C. The duration of intubation and IPPV before tracheostomy and the length of the whole performance (rounded) are in Table 3.

The whole exercise operation for the first 20 patients lasted $27 \pm 12$ minutes in average and for the last 20 cases only $15 \pm 5 \mathrm{~min}$. During this time we extubated the classic ET tube and after fixation of the TS cannula we introduced the HFJV-C and controled their position using a bronchoscope. In 11 patients ventilated with originally supplied score ET cannula the tracheostomic operation lasted $36 \pm 6$ minutes. With the use of HVJV-C the performance fell by an average of $9 \mathrm{~min}$ and after some experiences by 21 minutes, respectively. This time reduction is statistically significant ( $p<0.01-$ unpaired $t$-test). A larger problem is an increase of tracheal pressure, when turning of the cannula could partially block the tracheal lumen and interrupt the ventilation. We detected in our patients a limit pressure $(\mathrm{PIP}=\mathrm{Pt})>4 \mathrm{kPa}$ for maximum of $12 \pm 6 \mathrm{sec}$. Severe complications requiring medical interventions did not occurre. Other, mainly technical problems are analyzed in the Table 5.

The number of problems gradually decreased depending on experiences. Up to $90 \%$ of the problems were observed in the first 35 TLT. In the last 20 cases no technical difficulties and problems have occurred. In neither case was observed a small leaking any bleeding 
Using of the Insuflation pressure (Pin) in patients groups, divided according body weight

\begin{tabular}{|c|c|c|c|c|c|}
\hline Weight of patient (kg) & $\begin{array}{c}\text { Insuflation pressure } \\
-\mathrm{Pin}(\mathrm{kPa})\end{array}$ & $\begin{array}{l}\text { Frequency } F \\
\left(c \cdot \min ^{-1}\right)\end{array}$ & $\begin{array}{c}\text { MV (minute ventilation) } \\
\text { approximated } \\
\text { the model and } \mathbf{P} / \mathrm{t} \\
\text { curve }\left(1 . \mathrm{min}^{-1}\right)\end{array}$ & $\begin{array}{c}\text { Pt max }=\text { PIP } \\
\left(\mathrm{cm} \mathrm{H}_{2} \mathrm{O}\right)\end{array}$ & $\begin{array}{l}\text { PEEPi }=\text { Pt min } \\
\quad\left(\mathrm{cm} \mathrm{H}_{2} \mathrm{O}\right)\end{array}$ \\
\hline $60-80$ & $160-180$ & 120 & $18-25$ & $17 \pm 3$ & $3-4$ \\
\hline $81-99$ & $181-190$ & 120 & $23-30$ & $21 \pm 3$ & $3-4,5$ \\
\hline $100-130$ & $191-230$ & 120 & $31-37$ & $26 \pm 4$ & $4-5,5$ \\
\hline
\end{tabular}

around the punction site or saliva from the oral cavity to the respiratory tract. These problems were prevented safely by the Klain's effect. The mesured peak pressure and PEEP (minimum pressure in the trachea) are in Table 6. Following the introduction of the TS cannula, we performed a bronchoscopic control and at the end of operations in 16 from 148 patients a toilet with removing of tiny plugs was indicated.

\section{Discussion}

ALV during a tracheotomy is a problem that can be managed in different ways, which are more or less suitable or comfortable. A solution recommended by the instructions in the original package «tracheostomic set by Fantoni» is one option (1-3). Use of a long thin endotracheal cannula with a balloon provides, however, few problems. First, it may affect the ALV, because it has a high flow resistance (Rt). The resulting high resistance provides serious problems during ALV, requiring high inflation pressures, and especially with urgent PEEPi, whose value may exceed 12-17 $\mathrm{cm} \mathrm{H}_{2} \mathrm{O}$. High PEEPi is needed for adequate gas exchange, volume changes (VT, MV), increases in alveolar pressure with secondary peak value of more than $35-45 \mathrm{~cm}$ $\mathrm{H}_{2} \mathrm{O}$, depending on tractable lung Cst and tidal volume. These values are dangerous also in terms of barotrauma. High PEEPi itself represents a risk of pulmonary perfusion limitations, as well as reducing the preload of the right heart in the high intrathoracic pressure.

For the above problems arising particularly in our patients who are usually disabled after operations on the heart and/or on large vessels, we find another solution that would prevent the problems discussed above. There are many experiences with high frequency ventilation, even with «HFJV catheter» application during $>17$ years for reconstructive surgery in the tracheobronchial tree and lung operations. We have chosen this method of mechanical ventilation for tracheostomy by Fantoni $(6,7,8)$.

The main risk for HFJV catheter application is barotrauma. The most common airway obstruction arises proximally from the end of the catheter during expiration. The only possible prevention is an appropriate technical equipment for evaluation of airway pressure with automatic disconnection of the ventilator at a pressure limit. For the safety of patient this requirement could be realized due to the technical components of HF ventilators. Tracheal pressure monitoring and its continuous

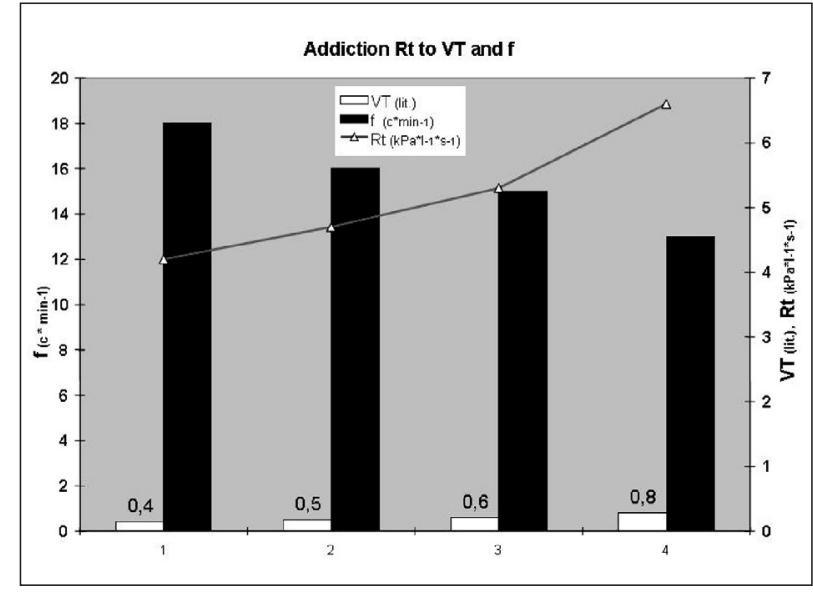

Fig. 6. Relationship between frequency, tidal volume and endotracheal tube resistance during conventional ventilation.

evaluation by the ventilator is an essential safety feature, which must be applied to any HFJV-C. In addition, use of a system identical with Fantoni`s tracheotomy was applied during HFJV-C bronchoskopic airway toilet and in some cases for bronchoscopy.

Application of ALV using a thin (biluminal) catheter is a safe method of ventilation with adequate gas exchange during tracheotomy, without increasing intraalveolar and intrathoracic pressures. The small diameter of the catheter presents practically no obstacle to turning the tracheostomic cannula in distal direction in the case of obstruction of the proximal part of tracheal cannula. Rotation and crossing of the TS cannula, evoking $\mathrm{Pt}>40 \mathrm{~cm} \mathrm{H}_{2} \mathrm{O}$, stops the breathing (ie. total stop). After good experiences with HFJV-C at tracheotomy by Fantoni, we are not using the original ET cannula for ALV. There are works preferering other methods of percutaneous dilatation tracheostomy, e. g. by Riggs and Caglia (4), but the results are not entirely clear from the guidelines. On the contrary, some authors (3.9) prefer Fantoni's tracheostomy.

\section{Conclusion}

Based on our experiences we consider the use of HFJV catheter, as a highly effective and safe method, applicable for Fantoni's tracheostomy. Pulmonary gas exchange is adequate and a slight decrease or increase in $\mathrm{PaCO}_{2}$ is not considered significant. Oxygenation measured by blood gas analysis or $\mathrm{SpO}_{2}$ was adequate in all cases. Peak alveolar pressure and PEEP are in appropriate 
borders of security and the activation of «total stop» of breathing by $\mathrm{Pt}>40 \mathrm{~cm} \mathrm{H}{ }_{2} \mathrm{O}$ proved to be also satisfactory. We believe that improving Fantoni's tracheostomy

References

1. Fantoni A. Translaryngeal tracheostomy. Gullo A. (ed.). APICE Trieste; 1993: 459-465.

2. Fantoni A., Ripamonti D. A breakthrough in tracheostomy techniques: translaryngeal tracheostomy. In: Roussos C. (ed.). Proceedings of 8th European congress of intensive care medicine. Athens; 1995: 1031-1034.

3. Platz A., Kleinstück F., Kohler A., Stocker R., Trentz O. Percutaneos tracheostomy: a minimally invasive procedur on the intensive care unit. Stois Surg. 1996; 2: 42-45.

4. Byhahn C., Wilke H.J., Lischke V., Rinne T., Westphal K. Bedside percutaneous tracheostomy: clinical comparison of Griggs and Fantoni techniques. World J. Surg. 2001; 25 (3): 296-301.

5. Konopke R., Zimmermann T., Volk A., Pyrc J., Bergert H., Blomenthal A. Gastmeier J., Kersting $S$. Prospective evaluation of the retrograde percutaneous translaryngeal tracheostomy (Fantoni procedure) in a surgical method is effective not only for ALV, but also in terms of improving and accelerating technology and operational procedures in general.

intensive care unit: technique and results of the Fantoni tracheostomy. Head Neck. 2006; 28 (4): 355-359.

6. Török P., Kálig $K$. Teoretičeskoe i kliničeskoe osnovy vysokočastotnoj ventilacii. Ekaterinburg, Ruská federácia: ABM; 2005: 190.

7. Kálig K., Haruštiak S., Brychta O., Yaghi A., Vlček Z., Ondrejovič S. HFJV in reconstructive surgery of trachea. In: Mutz N. J., Koller W., Benzer $\mathrm{H}$. Abstracts of 7 th European congress on intensive care. Insbruck; June 1994: 809-814.

8. Kálig K. Katétrová VFDV v rekoštrukčnej chirurgii trachey. Kandidátska dizertaáná práca. LF Univerzity Komenského v Bratislave, 1999.

9. Adam H., Hemprich A., Koch C., Oeken J., Schmidt H., Schramek J., Frerich B. Safety and practicability of percutaneous translaryngeal tracheotomy (Fantoni technique) in surgery of maxillofacial and oropharyngeal tumours - own results and review of the literature.J. Craniomaxillofac. Surg. 2008; 36 (1): 38-46.

Поступила 21.03.12

\section{КАЛЕНДАРЬ НАУЧНЫХ КОНГРЕССОВ, КОНФЕРЕНЦИЙ, СИМПОЗИУМОВ, ШКОЛ, СЕМИНАРОВ В 2013 гГ.}

13-15 мая, Геленджик, Россия

XII Всероссийская научно-методическая конференция с международным участием

«Стандарты и индивидуальные подходы

в анестезиологии и реаниматологии» wrow.kubanesth.narod.ru

22-24 мая, Москва, Россия

XIII Международный конгресс по антимикробной терапии МАКМAX/ESCMID wrere.antibiotic.ru

23-25 мая

Obstetric Anaesthesia 2013

wror.oaa-anaes.ac.uk

24-25 мая, Москва, Россия

II Международный Симпозиум по Нейрореанимации (НИИ нейрохирургии им. Н. Н. Бурденко) wrow.nsicu.ru

май, Одесса, Украина

«Анестезия и интенсивная терапия в акушерстве и гинекологии» wrore.anest-cfo.ru
1-4 июня, Barcelona, Spain

Euroanaesthesia 2013

wrore.euroanaesthesia.org

июнь, Москва, Россия

X Научно-практическая конференция «Безопасность больного в анестезиологии - реаниматологии» wroro.infomedfarmdialog.ru

20-21 июня, Архангельск, Россия

$\mathrm{V}$ Беломорский симпозиум wrow.anesth.ru/Belomorski_2013.pdf

27-29 июня, Иркутск, Россия

X Байкальский конгресс

«Актуальные проблемы анестезиологии и реаниматологии»

Дополнительная информация: http://wwow.researchraven.com/conferences/ category/acute-care.aspx 